\title{
Agronomic and molecular analyses for the characterisation of accessions in Tunisian olive germplasm collections
}

\author{
Wael Taamalli \\ Laboratoire Caractérisation et Qualité de l'Huile d'Olive \\ Centre de Biotechnologie \\ Technopole de Borj Cedria \\ BP 901, 2050, Hammam-Lif, Tunisia \\ Tel: 21671855430 \\ Fax: 21671855934 \\ E-mail: taamalli.wael@cbbc.rnrt.tn \\ Filippo Geuna \\ Dipartimento di Produzione Vegetale \\ Università degli Studi di Milano \\ Via Celoria 2, 20133, Milano, Italy \\ Tel: 390250316550 \\ Fax: 390250316553 \\ E-mail: filippo.geuna@unimi.it \\ Riccardo Banfi \\ Dipartimento di Produzione Vegetale \\ Università degli Studi di Milano \\ Via Celoria 2, 20133, Milano, Italy \\ Tel: 390250316550 \\ Fax: 390250316553 \\ E-mail: riccardo.anfi@unimi.it \\ Daniele Bassi \\ Dipartimento di Produzione Vegetale \\ Università degli Studi di Milano \\ Via Celoria 2, 20133, Milano, Italy \\ Tel: 390250316550 \\ Fax: 390250316553 \\ E-mail: daniele.bassi@unimi.it

\section{Douja Daoud} \\ Laboratoire Caractérisation et Qualité de l'Huile d'Olive \\ Centre de Biotechnologie \\ Technopole de Borj Cedria \\ BP 901, 2050, Hammam-Lif, Tunisia \\ Tel: 21671855430 \\ Fax: 21671855934 \\ E-mail: douja.daoud@cbbc.rnrt.tn

\section{Mokhtar Zarrouk*} \\ Laboratoire Caractérisation et Qualité de l'Huile d'Olive \\ Centre de Biotechnologie \\ Technopole de Borj Cedria \\ BP 901, 2050, Hammam-Lif, Tunisia \\ Tel: 21671855430 \\ Fax: 21671855934 \\ E-mail: mokhtar.zarrouk@cbbc.rnrt.tn
}

Financial support: The present work has been done in the framework of a research programme (2002-2005) funded by the Tunisian Ministry of Science Research, Technology and Competency Development.

Keywords: agronomic traits, AFLP, Olea europaea, SSR.

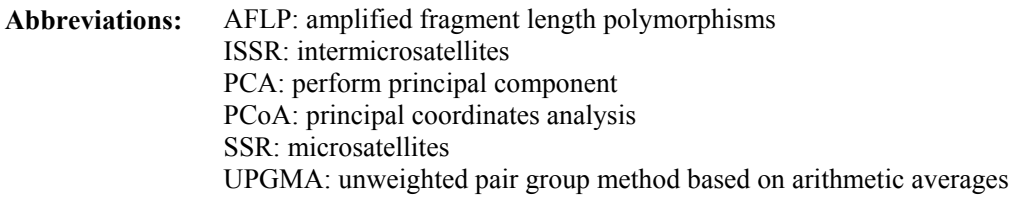

*Corresponding author 
In this study, a total of 14 agronomic traits, five AFLP primer combinations and ten SSR loci were used to describe and to classify a group of Tunisian olive genotypes into groups based on molecular profiles and agronomic traits. The analysis of variance of the agronomical data revealed significant differences among accessions for all measured traits. The mean phenotypic dissimilarity (0.34 with a range of 0.08-0.6) was low in comparison to dissimilarity calculated using AFLP (0.50 with a range of 0.16-0.70) and SSR markers (0.76 with a range $0.35-0.94)$. The correlation between the agronomical dissimilarity matrix and the matrices of genetic dissimilarity based on SSR and AFLP markers was very weak: $0.156(p=0.05)$ and $0.185(p=$ 0.05), respectively. The SSR-AFLP dendrogram based on unweighted pair-group cluster analysis using Jaccard's index revealed that the genetic diversity was predominantly structured according to fruit size. A trend of clustering together of accessions originating from the same or adjacent regions was also observed. The data obtained can be used for the varietal survey and construction of a database of all olive varieties grown in Tunisia and providing also additional information that could form the basis for the rational design of breeding programs.

The olive tree (Olea europaea L.) is a subtropical species typical of the Mediterranean basin where it represents the most important oil-producing crop. It is a diploid, out crossing species with a very wide genetic patrimony. Since the beginning of its domestication, olive has been propagated vegetatively to exploit the best combination of genes which arose by random crosses or mutations (Carriero et al. 2002). As a result, a great number of varieties are present in all the countries where this species is cultivated, raising several problems for germplasm management and preservation (Carriero et al. 2002). Evaluation and characterisation of olive genetic resources is therefore crucial, since identification of olive cultivars is complicated by the large number of varietal synonyms and homonyms, the intensive exchange of plant material, the presence of varietal clones, and problems of varietal certification in nurseries (Bandelj et al. 2002).

Morphological and biological characters have been widely used for descriptive purposes and are commonly used to distinguish olive cultivars (Cantini et al. 1999). Agronomic characterization also allowed the classification of different olive cultivars (Barranco and Rallo, 2000). In order to supplement and refine the initial phenotypical based descriptions, different genetic markers such as randomly amplified polymorphic DNA (RAPD) markers (Fabbri et al. 1995; Wiesman et al. 1998; Belaj et al. 2001; Besnard et al. 2001b; Sanz-Cortés et al. 2001; Nikoloudakis et al. 2003), amplified fragment length polymorphisms (AFLP) (Angiolillo et al. 1999; Rotondi et al. 2003; Sanz-Cortés et al. 2003; Sensi et al. 2003), microsatellites (SSR) (Carriero et al. 2002; Cipriani et al. 2002) and intermicrosatellites (ISSR) (Hess et al. 2000) have been applied to identify and characterize different cultivars or genotypes and in order to provide information on olive origin and dispersal.

Tunisia occupies the fourth place on world scale in terms of olive oil production. Tunisian olive plantations count about 63 million trees covering 1.6 million of hectares and estimated to include more than 50 cultivars. Despite this economic importance, little is known about the olive germplasm of this country and about the genetic relationships among them. In fact Tunisian olive tree is dominated by the variety-population 'Chemlali' that occupies more than $2 / 3$ of the total olive growing area. It is a cultivar for oil production, well adapted to arid and semiarid zones but its oil shows physico-chemical drawbacks (high saturated-fatty acids content, notably the palmitic acid, a high level of linoleic acid and a low level of oleic acid). Whereas a wide range of minor cultivars are cultivated around their presumed areas of origin and have a limited diffusion outside these areas. The study of these less-common cultivars appears of particular interest because they may have agronomic characteristics which can be relevant to olive growers. The objectives of this paper are: to describe relationships among Tunisian olive cultivars using agronomic and molecular markers, to assess the correlation between distance estimates based on agronomic characterisation and AFLP and SSR molecular markers, and to classify the cultivars into groups based on molecular profiles and agronomic traits.

\section{MATERIALS AND METHODS}

\section{Plant material}

Agronomic and molecular analyses were performed on 26 olive (Olea europaea L.) accessions: 25 accessions belonging to 25 cultivars and one accession without denomination. These were obtained from four collections maintained in experimental orchards at the 'Institut de l'Olivier' (IO), 'Institut National des Sciences Appliquées et de la Technologie' (INSAT), 'Centre de Biotechnologie de Borj Cedria' (CBBJ) and Sbitla (Kasserine). Denominations of genotypes are provided in Table 1.

\section{Agronomic and chemical characters}

Some agronomic and biochemical characteristics were measured or analyzed as mean of 2003 and 2004 (Table 2). At the mature stage, 200 olives ( 3 replicates per genotype) were picked randomly and then split in two samples, one put in oven to dry, the other used for fresh fruit and pit analysis and fatty acids determination. Average fruit weight was determined and, after removing and cleaning the stones, flesh and stone weights were also recorded. Oil content was determined by extracting the dry material with $40-60^{\circ} \mathrm{C}$ petroleum ether using a Soxhlet apparatus. Olive oil used for the qualitative analysis was extracted from fresh material using methanol-chloroform (1:1, v/v) according to Allen and Good (1971). Fatty acids were determined, as methyl ester, by gas chromatography. Methylesters were released by transesterefication with 
$\mathrm{BF} 3 /$ methanol after saponification with methanolic $\mathrm{KOH}$. The fatty acid pattern was assessed with a HP 4890 D (Agilent Technologies) equipped with a split-splitless injector, a FID detector and a $30 \mathrm{~m} \mathrm{X} 0.25 \mathrm{~mm}$ fused silica capillary column coated with a $0.25 \mu \mathrm{m}$ film (HP Innowax). The temperatures of the injector, detector and oven were 230,250 and $210^{\circ} \mathrm{C}$ respectively. The carrier gas was nitrogen, with a flow through the column of $1 \mathrm{ml} / \mathrm{min}$. The data resulting from the two-year study were averaged and used for statistical analysis.

\section{DNA extraction}

Five hundred milligrams of young leaves were collected, rinsed with tap water, frozen in liquid nitrogen, ground to a fine powder in a reciprocal grinding apparatus (Mixer Mill MM300, Retsch, Haan, Germany) and kept at $-80^{\circ} \mathrm{C}$ until DNA isolation. Genomic DNA was extracted from the ground tissue according to Geuna et al. (2003). DNA yield and quality were assessed by gel electrophoresis using standards.

\section{Microsatellite assay}

Ten developed primer pairs for olive microsatellite loci (Sefc et al. 2000) were selected for their polymorphism and the clarity of their electrophoretic profiles. The loci amplified by these primer pairs were designated as: ssrOeUA-DCA1, ssrOeUA-DCA3, ssrOeUA-DCA4, ssrOeUA-DCA7, ssrOeUA-DCA9, ssrOeUA-DCA11 ssrOeUA-DCA13, ssrOeUA-DCA15, ssrOeUA-DCA16 and ssrOeUADCA18. PCR reactions were performed in a total volume of $20 \mu \mathrm{L}$ containing $100 \mathrm{mM}$ Tris- $\mathrm{HCl}(\mathrm{pH}$ 9.0), $50 \mathrm{mM} \mathrm{KCl}, 1.5 \mathrm{mM} \mathrm{MgCl} 2,0.2 \mathrm{mM}$ each dNTP, $0.125 \mu \mathrm{M}$ each primer, $0.2 \mathrm{U}$ of Taq DNA Polymerase (Platinum Taq DNA Polymerase, Invitrogen) and $10 \mathrm{ng}$ of template DNA. To enable the detection and sizing of PCR fragments, the forward primer was labelled with $\gamma_{-}{ }^{33} \mathrm{P}$-ATP (Perkin-Elmer). PCR products were mixed with an equal volume of loading buffer ( $95 \%$ formamide, $200 \mu \mathrm{M}$ EDTA, $0.1 \%$ bromophenol blue and $0.1 \%$ xylene cyanol) and denatured at $95^{\circ} \mathrm{C}$ for $5 \mathrm{~min}$. Then, $5 \mu \mathrm{L}$ of each sample was loaded on a $6 \%$ denaturating polyacrylamide gel. The gel was run in $1 \mathrm{X}$ TBE buffer $(0.089 \mathrm{M}$ Tris-borate, 0.002 M EDTA, pH 8.3) at constant power of $60 \mathrm{~W}$ for 1-2 hrs. After electrophoresis, the gel was fixed for $25 \mathrm{~min}$ in $10 \%$ acetic acid, rinsed with water three times for 2 min each, dried and exposed to autoradiographic film (Hyperfilm MP, Amersham) for 3 to 5 days. The fragments amplified by microsatellite primers were scored as alleles on the basis of size in comparison with a molecular weight marker (10 bp DNA Ladder, Invitrogen).

\section{AFLP assay}

The AFLP protocol was performed according to the procedure described by Vos et al. (1995). $500 \mathrm{ng}$ of genomic DNA was double digested with EcoRI and MseI enzymes (2.5 U each) and linked to adapters (50 and 5 pmols of MseI and EcoRI adapters, respectively). Restricted and ligated DNA (25 ng) was then pre-amplified using EcoRI and MseI primers (25 ng) with one selective nucleotide. PCR pre-amplifications were prepared in a total volume of $25 \mu \mathrm{l}$ and amplification was carried out in a PTC-100 thermal cycler (MJ Research Inc., Watertown, MA, USA), using 20 cycles of $92^{\circ} \mathrm{C}$ for $30 \mathrm{sec}, 60^{\circ} \mathrm{C}$ for 30 sec and $72^{\circ} \mathrm{C}$ for $60 \mathrm{sec}$. The pre-amplification products, diluted 1:10, were used as template for selective amplifications using a total of five primer combinations (15 ng of each) with three selective nucleotides (EcoRIAAC/MseI-CAA, EcoRI-AAC/MseI-CAC, EcoRIAAG/MseI-CAA， EcoRI-ACT/MseI-CAA，EcoRIAAC/MseI-CTT). EcoRI primers were end-labeled with $\gamma$ -

${ }^{33} \mathrm{P}$-ATP (Perkin-Elmer), and selective amplification was carried out in a $10 \mu \mathrm{L}$ volume using the following temperature profile: 12 cycles of $94^{\circ} \mathrm{C}$ for $30 \mathrm{sec}, 65^{\circ} \mathrm{C}$ for $30 \mathrm{sec}$ with a decrease of annealing temperature of $0.7^{\circ} \mathrm{C}$ per cycle, and $72^{\circ} \mathrm{C}$ for $1 \mathrm{~min}$, followed by 24 cycles at the annealing temperature of $56^{\circ} \mathrm{C}$. PCR products were resolved on a $6 \%$ polyacrylamide denaturating gel, visualised by autoradiography and manually scored for the presence or absence of bands. The reproducibility of the AFLP fingerprints was assessed on two DNA samples by replicating the entire procedure starting from the original DNA for all the primer combinations. No unstable bands were detected.

\section{Data analysis}

Analysis of variance was performed for all measured traits in order to test the significance of variation among accessions. The standardized traits mean values (mean of each trait was subtracted from the data values and the result divided by the standard deviation) were used to perform principal component (PCA) and cluster analyses using XLSTAT software. To group the accessions based on agronomical dissimilarity, cluster analysis was conducted on the Euclidean distance matrix with the unweighted pair group method based on arithmetic averages (UPGMA).

For molecular diversity analysis, AFLP and microsatellite results were scored for presence (1) or absence (0) of amplified markers. Genetic distance was calculated on the basis of Jaccard's coefficient method (Jaccard, 1908). The combined SSR-AFLP similarity matrix was subjected to cluster analysis by UPGMA. The individual SSR-AFLP genotypes scores were plotted in a bidimensional space using principal coordinates analysis ( $\mathrm{PCoA}$ ) by computing the genetic distance matrix using the GENSTAT software, $8^{\text {th }}$ edition. The relationships between the Euclidean distance matrix based on agronomic traits and genetic distance matrices obtained with SSR and AFLP markers were analyzed according to Mantel (1967). 


\section{RESULTS}

\section{Phenotypic variability}

The analysis of variance revealed significant differences among accessions for all of the studied traits (Table 3). The average fruit fresh and dry weights, flesh and pit fresh weights and palmitoleic acid percentage showed wide variation, while fruit oil content on dry weight basis and oleic acid percentage showed a narrower range of phenotypic variation. The 14 studied variables were analysed by PCA (data not shown). The eigenvalues obtained by PCA on the agronomic data indicate that two to three components provide a good summary of the data. In particular, the first two components (PC1 and $\mathrm{PC} 2$ ) accounted for $56.7 \%$ of total variance, and three components explained $68.8 \%$. The other components contribute less than $10 \%$ each. Variables such as fruit fresh and dry weights, flesh and pit fresh weights (on PC1), palmitic and oleic acids percentages and fruit oil content on fresh and dry weight basis (on PC2) explained the largest portion of the variance. In the third PC, which explained $12.1 \%$ of total variation, the predominating traits were fatty acid percentages (excluding oleic acid).

\section{Molecular analysis}

The two molecular approaches used in this study could uniquely fingerprint each of the 26 olive accessions. The 5 primer combinations used to perform the AFLP analysis yielded a total of 418 bands with a percentage of polymorphism of $56.46 \%$ (Table 4). Only 129 well-defined bands were analysed in the whole set of data. A typical AFLP band pattern for the 26 accessions is shown in Figure 1a. Microsatellites were successfully amplified in all the analysed accessions with the ten primer pairs used. Patterns generated by primer pair ssrOeUA-DCA18 in accessions are shown in Figure 1b. All ten microsatellite markers were polymorphic across the screened genotypes, revealing a total of 86 alleles. The number of alleles for each locus varied from four at locus ssrOeUA-DCA15 to fourteen at locus ssrOeUA-DCA4, with an average of 8.6 (Table 5).

\section{Distribution of dissimilarity coefficients}

A histogram of pair wise dissimilarity for the 26 Tunisian olive accessions generated from SSR, AFLP and agronomic data is presented in Figure 2. The dissimilarity coefficients based on agronomic traits ranged from 0.08 to 0.60 with an average of 0.34. Based on SSR, these values ranged from 0.35 to 0.94 with an overall mean of 0.76 . For AFLP, it ranged from 0.16 to 0.70 with an overall mean of 0.50 .

\section{Correlations between dissimilarity matrices}

To compare the extent of agreement between dendrograms derived from agronomic, AFLP and SSR data, a distance matrix was constructed for each assay and compared using the Mantel matrix correspondence test. The estimated correlation for the two molecular systems was significant but relatively low $(\mathrm{r}=0.3, \mathrm{p}=0.001)$. The AFLP and SSR data were poorly correlated with the agronomic data $(\mathrm{r}$ $=0.185, \mathrm{p}=0.05$ and $\mathrm{r}=0.156, \mathrm{p}=0.05$, respectively).

A dendrogram generated from the standardized phenotypic data is presented in Figure 3. The UPGMA cluster analysis revealed three main groups. Group 1 consisted of 'Meski', 'Injassi', 'Besbassi' and 'Marsaline', four accessions featuring large-sized fruits (4.95-9.22 g); the first three accessions are among the most important Tunisian table cultivars, whereas the letter is used for both oil and canning. 'Swabaa Algia', a medium-sized table olive clustered also within this group. Group 2 comprised two subgroups. One of them comprised six accessions used for both oil and canning ('Ain Jarboua', 'Mongar Ragma', 'Regregui', 'Chemchali', 'Zarrazi' and 'Sayali') that have medium-sized fruits $(2.4-4 \mathrm{~g})$, medium oil content (42$56 \%)$, high oleic $(70.9-81 \%)$ and low linoleic $(3.7-13.3 \%)$ acids contents. Five oil-producing accessions 'Rakhami', 'Oueslati', 'Semni', 'Chétoui' and 'Dhokkar', as well as the accession 'Gerboui', which has dual uses (oil and table) clustered together in the second subgroup. Small fruit size (1.3-2.4 g) and high linoleic acid content (14.6-22.5\%) characterized accessions in this subgroup. The accessions 'Unknown', 'Neb Djemel' and 'Toffahi' also branched in the second group at a higher value of dissimilarity. Group 3 included 6 accessions, all used for oil production, with very small fruits (1-1.5 g) and oils rich in palmitoleic acid (2.1$2.3 \%)$.

The dendrogram generated based on a combined SSR and AFLP data set (Figure 4) showed three main groups: Group A, including 6 accessions, Group B, including 5 accessions and Group C, with 13 accessions, while 'Sayali' and 'Jemri Dhokkar' showed the lowest similarity to all accessions and were set apart from the three clusters. Group A consisted of six Southern accessions originating from the arid regions of Sfax ('Semni', 'Kbiret Louzir', 'Unknown', 'Chemlali' and 'Kchinet Sig') and Zarzis ('Dhokkar'). All accessions in this cluster have small-sized fruits and are typically used for oil production. Group B comprised five small-fruited accessions used for oil production. Two of them originate from the North of Tunisia ('Chétoui' and 'Rakhami'); two ('El Hor' and 'Oueslati') originate from the semiarid zones of El Ala and Oueslatia (Kairouan, Centre of Tunisia), the accession 'Jdallou' comes from the South of the country. Group C included 13 accessions that have either mediumor large-sized fruits and showed two subgroups. One of them comprised three medium-fruited accessions, 'Mongar Ragma' and 'Swabaa Algia', whose zones of origin are uncertain, and the accession 'Regregui' from Northern Tunisia. The accessions 'Injassi', 'Chemchali' and 'Toffahi' from the South (Gafsa and Tataouine) as well as the accessions 'Meski', 'Besbassi' and 'Ain Jarbouaa' from the North clustered together in the second subgroup. The accessions 'Marsaline', 'Zarrazi' as well as the pair 'Regregui'-'Neb Djemel' branched also in the second subgroup rather independently from the other accessions. 
The principal coordinates analysis (Figure 5) where the first two principal components accounted for $33.5 \%$ of the variance, seems to support the results obtained by cluster analysis. The pattern shown in Figure 4 was comparable to the clustering observed in the UPGMA dendrogram (Figure 5). With the exception of 'Sayali', genotypes that have either medium or large-sized fruits were scattered separated from the small-fruited genotypes. Again with one exception ('Jdallou'), the PCoA separated the Southern oil producing accessions from those originating from the North and the Centre of Tunisia.

\section{DISCUSSION}

In this study, we used AFLP and SSR markers and agronomic traits to characterize a set of 26 Tunisian olive accessions. Polymorphism was evident for all three marker systems. This result is consistent with results from previous studies carried out on olive cultivars (Fabbri et al. 1995; Wiesman et al. 1998; Angiolillo et al. 1999; Baldoni et al. 2000; Rallo et al. 2000; Belaj et al. 2001; Besnard et al. 2001b; Sanz-Cortés et al. 2001), thereby confirming the great diversity within the cultivated olive germplasm. The distribution of values for agronomic dissimilarity and genetic dissimilarity (calculated with SSRs and AFLPs) differed markedly. The mean agronomic dissimilarity $(0.34$ with a range of 0.08-0.6) was low in comparison to dissimilarity calculated using AFLP ( 0.50 with a range of 0.16-0.70) and SSR markers (0.76 with a range 0.35-0.94). This data suggest that SSR and AFLP markers can better differentiate pairs of accessions than agronomic traits that show a low level of genetic variation. Comparing the two marker types, a higher level of polymorphism was obtained for SSR than for AFLP (Table 6) which highlights the discriminating power of the former. This result is in accordance with previous studies where SSRs were compared to other marker systems (Powell et al. 1996; Pejic et al. 1998; Belaj et al. 2003). The high variability observed at SSR loci was expected because of the unique mechanism by which this variation is generated: replication slippage is thought to occur more frequently than single nucleotide mutations and insertion/deletion events, which generate the polymorphisms detectable by AFLP analysis (Powell et al. 1996; Milbourne et al. 1997).

To provide an objective comparison, we examined correlations between distance matrices calculated on the basis of AFLP, SSR and agronomical data using a Mantel matrix correspondence test. The estimated correlation similarities for the two molecular systems was significant but relatively low. The type of genetic polymorphism detected by the two markers and the number of primers used may affect the correlations among them. The correlation between the two molecular markers was higher than the agronomy. When compared with DNA fingerprinting techniques, agronomic traits are relatively less reliable and efficient for precise discrimination of closely related accessions and analysis of their genetic relationships. Despite this limitation, numerical analysis of olive agronomic traits can be used as a general approach to establish from a practical viewpoint a first order of accessions classification within germplasm collections; it enables accession comparison and diversity conservation. Although both marker methods did not provide exactly the same description of relationships between the analysed accessions, there was some consistency. The best agreement between the two methods was present for accession pairs that were very distant (e.g. 'Besbassi''Chemlali', 'Besbassi'-'Jemri Dhokkar', 'Zarrazi'-'Kchinet Sig') or very close (e.g. 'El Hor'- 'Jdallou' and, to a lesser extent, 'Chemlali'-'Kchinet Sig', 'Meski'-'Besbassi').

The UPGMA clustering and the PCoA Plot obtained from the AFLP-SSR distance matrix showed a rather high variability among the accessions examined and that most of Tunisian olive accessions clustered according to their fruit size. For instance small-fruited accessions clustered in Group A and B. Accessions that have medium to large sized-fruits clustered in Group C. Genetic differentiation based on fruit size and use has been observed in previous studies. Grati-Kamoun et al. (2006), in their AFLP study, obtained a clustering of olive cultivars into two main groups according to fruit size. Interestingly, of the 29 cultivars included in their study, ten Tunisian cultivars are also included here. Grati-Kamoun et al. (2006) found a comparable grouping pattern among 'Jemri Dhokkar', 'Chemlali', and 'Oueslati' that were grouped with the small-sized cultivars and 'Marsaline', 'Meski', and 'Besbassi' that were in the cluster of the large-fruited cultivars. The same above-mentioned work showed that 'Zarrazi', 'Chemchali' and 'Toffahi', three medium-fruited cultivars from Southern Tunisia, clustered with the smallsized olives originating from the same part of the country while in our assay, these cultivars were not well separated from those used for canning. The presence of table olives from other Mediterranean countries in Grati-Kamoun et al. (2006) study could change the clusters of these cultivars in the Jaccard's dendrogram. In a study based on RAPD markers, (Fabbri et al. 1995) seventeen olive cultivars clustered into two main groups according to fruit size and oil content. Using the same technique, Nikoloudakis et al. (2003) reported that most of Greek cultivars clustered according to their fruit size or commercial use. Another group (Loukas and Krimbas, 1983) studied 22 Greek cultivars based on allozyme markers and found clustering according to fruit size rather than to geographic origin. Wild and feral olives are characterized by very small fruits. The relationship between electrophoretic profiles and the common utilisation of fruits (oil, canning, or both uses) may be due either to a single origin of varieties with big fruits or to their less-close proximity with wild populations due to a stronger or longer selection towards fruit size (Besnard et al. 2001a). A trend of clustering of cultivars originating from the same or adjacent regions was also detected. With the exclusion of 'Jdallou', Southern oil producing cultivars clustered separated from those originating from the North and the Centre of Tunisia. This was also the case for the pairs of northern cultivars, 
'Gerboui'-'Neb Djemel' and 'Meski'-'Besbassi' which feature medium- and large-sized fruits, respectively. 'Toffahi', 'Chemchali' and 'Injassi', three accessions originating from the South, formed a small separate cluster, which does not include the accession 'Zarrazi'. The three first accessions come from interior regions (Gafsa and Tataouine) where weather conditions are different from coastal regions such as Zarzis from where originated the accession 'Zarrazi'. Clustering of cultivars according to their geographic origin was also observed in a larger geographic scale study performed by Belaj et al. (2001) with cultivars from several countries of the Mediterranean Basin. The geographic and genetic structure was not exclusively observed among cultivars of different countries, but also within cultivars of the same country (Claros et al. 2000; Carriero et al. 2002). Moreover, in a specific region of Spain, Sanz-Cortés et al. (2001) also observed subclustering according to the geographic origin within that region. The clustering of the cultivars from the same or nearby region suggests a common genetic base and an autochthonous origin for these cultivars. This result agrees with the hypothesis of autochthonous origin of most of the olive cultivars as well as their limited diffusion from their centres of origin (Barranco and Rallo, 2000; Belaj et al. 2001; Besnard et al. 2001a). Cultivar intercrossing and crosses with wild accessions, along with local selection of outstanding seedlings and subsequent vegetative cloning, could have led to a large number of varieties around their possible original areas of cultivation.

\section{REFERENCES}

ALLEN, C. Freeman and GOOD, Pearl. Acyl lipids in photosynthetic systems. Methods in Enzymology: Photosynthesis and Nitrogen Part A, 1971, vol. 23, p. 523547.

ANGIOLILLO, A.; MENCUCCINI, M. and BALDONI, L. Olive (Olea europaea L.) genetic diversity assessed by amplified fragment length polymorphisms. Theoretical and Applied Genetics, March 1999, vol. 98, no. 3-4, p. 411-421.

BALDONI, L.; PELLEGRINI, M.; MENCUCCINI, M.; MULAS, M. and ANGIOLILLO, A. Genetic relationships among cultivated and wild olives revealed by AFLP markers. Acta Horticulturae, January 2000, vol. 521, no. 11, p. 275-283.

BANDELJ, Dunja; JAKŠE, Jernej and JAVORNIK, Branka. DNA fingerprinting of olive varieties by microsatellite markers. Food Technology and Biotechnology, July-September 2002, vol. 40, no. 3, p. 185190.

BARRANCO, Diego and RALLO, Luis. Olive cultivars in Spain. HortTechnology, January-March 2000, vol. 10, no. 1, p. 107-110.
BELAJ, A.; TRUJILLO, I.; DE LA ROSA, R.; RALLO, L. and GIMÉNEZ, M.J. Polymorphism and discriminating capacity of randomly amplified polymorphic markers in an olive germplasm bank.Journal of the American Society for Horticultural Science, January 2001, vol. 126, no. 1, p. 6471.

BELAJ, A.; SATOVIC, Z.; CIPRIANI, G.; BALDONI, L.; TESTOLIN, R.; RALLO, L. and TRUJILLO, I. Comparative study of the discriminating capacity of RAPD, AFLP and SSR markers and of their effectiveness in establishing genetic relationships in olive. Theoretical and Applied Genetics, August 2003, vol. 107, no. 4, p. 736-744.

BESNARD, Guillaume; BARADAT, Philippe and BERVILLE, André. Genetic relationships in the olive (Olea europaea L.) reflect multilocal selection of cultivars. Theoretical and Applied Genetics, February 2001a, vol. 102, no. 2-3, p. 251-258.

BESNARD, Guillaume; BRETON, Catherine; BARADAT, Philippe; KHADARI, Bouchaib and BERVILLE, André. Cultivar identification in olive based on RAPD markers. Journal of the American Society for Horticultural Science, November 2001b, vol. 126, no. 6, p. 668-675.

CANTINI, Claudio; CIMATO, Antonio and SANI, Graziano. Morphological evaluation of olive germplasm present in Tuscany region. Euphytica, October 1999, vol. 109, no. 3, p. 173-181.

CARRIERO, F.; FONTANAZZA, G.; CELLINI, F. and GIORIO, G. Identification of simple sequence repeats (SSRs) in olive (Olea europaea L.) Theoretical and Applied Genetics, February 2002, vol. 104, no. 2-3, p. 301307.

CIPRIANI, G.; MARRAZZO, M.T.; MARCONI, R.; CIMATO, A. and TESTOLIN, R. Microsatellite markers isolated in olive are suitable for individual fingerprinting and reveal polymorphism within ancient cultivars (Olea europaea L.) Theoretical and Applied Genetics, February 2002, vol. 104, no. 2-3, p. 223-228.

CLAROS, M. Gonzalo; CRESPILLO, Remedios; AGUILAR, Maria L. and CANOVAS, Francisco M. DNA fingerprinting and classification of geographically related genotypes of olive-tree (Olea europaea L.) Euphytica, November 2000, vol. 116, no. 2, p. 131-142.

FABBRI, A.; HORMAZA, J.I. and POLITO, V.S. Random amplified polymorphic DNA analysis of olive (Olea europaea L.) cultivars. Journal of the American Society for Horticultural Science, May 1995, vol. 120, no. 3, p. 538542.

GEUNA, F.; TOSCHI, M. and BASSI, D. The use of AFLP markers for cultivar identification in apricot. Plant Breeding, December 2003, vol. 122, no. 6, p. 526-531. 
GRATI-KAMOUN, N.; MAHMOUD, F. Lamy; REBAI, A.; GARGOURI, A.; PANAUD, O. and SAAR, A. Genetic diversity of Tunisian olive tree (Olea europaea L.) cultivars assessed by AFLP markers. Genetic Resources and Crop Evolution, March 2006, vol. 53, no. 2, p. 265-275.

HESS, J.; KADEREIT, J.W. and VARGAS, P. The colonization history of Olea europaea L. in Macaronesia based on internal transcribed spacer 1 (ITS-1) sequences, randomly amplified polymorphic DNAs (RAPD), and intersimple sequence repeats (ISSR) Molecular Ecology, July 2000 , vol. 9 , no. 7 , p. 857-868.

JACCARD, P. Nouvelle recherches sur la distribution florale. Bulletin de la Société Vaudoise des Sciences Naturelles, 1908, vol. 44, p. 223-270.

LOUKAS, M. and KRIMBAS, C.B. History of olive cultivars based on their genetic distances. Journal of Horticultural Science, 1983, vol. 58, no. 2, p. 121-127.

MANTEL, N. The detection of disease clustering and a generalized regression approach. Cancer Research, February 1967, vol. 27, no. 2, p. 209-220.

MILBOURNE, Dan; MEYER, Rhonda; BRADSHAW, John E.; BAIRD, Eileen; BONAR, Nicky; PROVAN, Jim; POWELL, Wayne and WAUGH, Robbie. Comparison of PCR-based marker systems for the analysis of genetic relationships in cultivated potato. Molecular Breeding, April 1997, vol.3, no. 2, p. 127-136.

NIKOLOUDAKIS, N.; BANILAS, G.; GAZIS, F.; HATZOPOULOS, P. and METZIDAKIS, J. Discrimination and genetic diversity among cultivated olives of Greece using RAPD markers. Journal of the American Society for Horticultural Science, September 2003, vol. 128, no. 5, p. 741-746.

PEJIC, I.; AJMONE-MARSAN, P.; MORGANTE, M.; KOZUMPLICK, V.; CASTIGLIONI, P.; TARAMINO, G. and MOTTO, M. Comparative analysis of genetic similarity among maize inbred lines detected by RFLPs, RAPDs, SSRs and AFLPs. Theoretical and Applied Genetics, December 1998, vol. 97, no. 8, p. 1248-1255.

POWELL, Wayne; MORGANTE, Michele; ANDRE, Chaz; HANAFEY, Michael; VOGEL, Julie; TINGEY, Scott and RAFALSKI, Antoni. The comparison of RFLP, RAPD, AFLP and SSR (microsatellite) markers for germplasm analysis. Molecular Breeding, September 1996, vol. 2, no. 3, p. 225-238.

RALLO, P.; DORADO, G. and MARTIN, A. Development of simple sequence repeats (SSRs) in olive tree (Olea europaea L.) Theoretical and Applied Genetics, October 2000, vol. 101, no. 5-6, p. 984-989.

ROTONDI, A.; MAGLI, M.; RICCIOLINI, C. and BALDONI, L. Morphological and molecular analyses for the characterization of a group of Italian olive cultivars. Euphytica, July 2003, vol. 132, no. 2, p. 129-137.

SANZ-CORTÉS, F.; BADENES, M.L.; PAZ, S.; IÑIGUEZ, A. and LLÁCER, G. Molecular characterization of olive cultivars using RAPD markers. Journal of the American Society for Horticultural Science, January 2001, vol. 126, no.1, p. 7-12.

SANZ-CORTÉS, F.; PARFITT, D.E.; ROMERO, C.; STRUSS, D.; LLÁCER, G. and BADENES, M.L. Intraspecific olive diversity assessed with AFLP. Plant Breeding, April 2003, vol. 122, no. 2, p. 173-177.

SEFC, K.M.; LOPES, M.S.; MENDONÇA, D.; RODRIGUES DOS SANTOS, M.; DA CAMARA MACHADO, M. Laimer and DA CAMARA MACHADO, A. Identification of microsatellite loci in olive (Olea europaea) and their characterisation in Italian and Iberian olive trees. Molecular Ecology, August 2000, vol. 9, no. 8, p. 1171-1193.

SENSI, E.; VIGNANI, R.; SCALI, M.; MASI, E. and CRESTI, M. DNA fingerprinting and genetic relatedness among cultivated varieties of Olea europaea L. estimated by AFLP analysis. Scientia Horticulturae, February 2003, vol. 97, no. 3-4, p. 379-388.

VOS, Pieter; HOGERS, Rene; BLEEKER, Marjo; REIJANS, Martin; VAN DE LEE, Theo; HORNES, Miranda; FRITERS, Adrie; POT, Jerina; PALEMAN, Johan; KUIPER, Martin and ZABEAU, Marc. AFLP: A new technique for DNA fingerprinting. Nucleic Acids Research, January 1995, vol. 23, no. 21, p. 4407-4414.

WIESMAN, Z.; AVIDAN, N.; LAVEE, S. and QUEBEDEAUX, B. Molecular characterization of common olive varieties in Israel and the West Bank using randomly amplified polymorphic DNA (RAPD) markers. Journal of the American Society for Horticultural Science, September 1998, vol. 123, no. 5, p. 837-841. 


\section{APPENDIX}

\section{FIGURES}
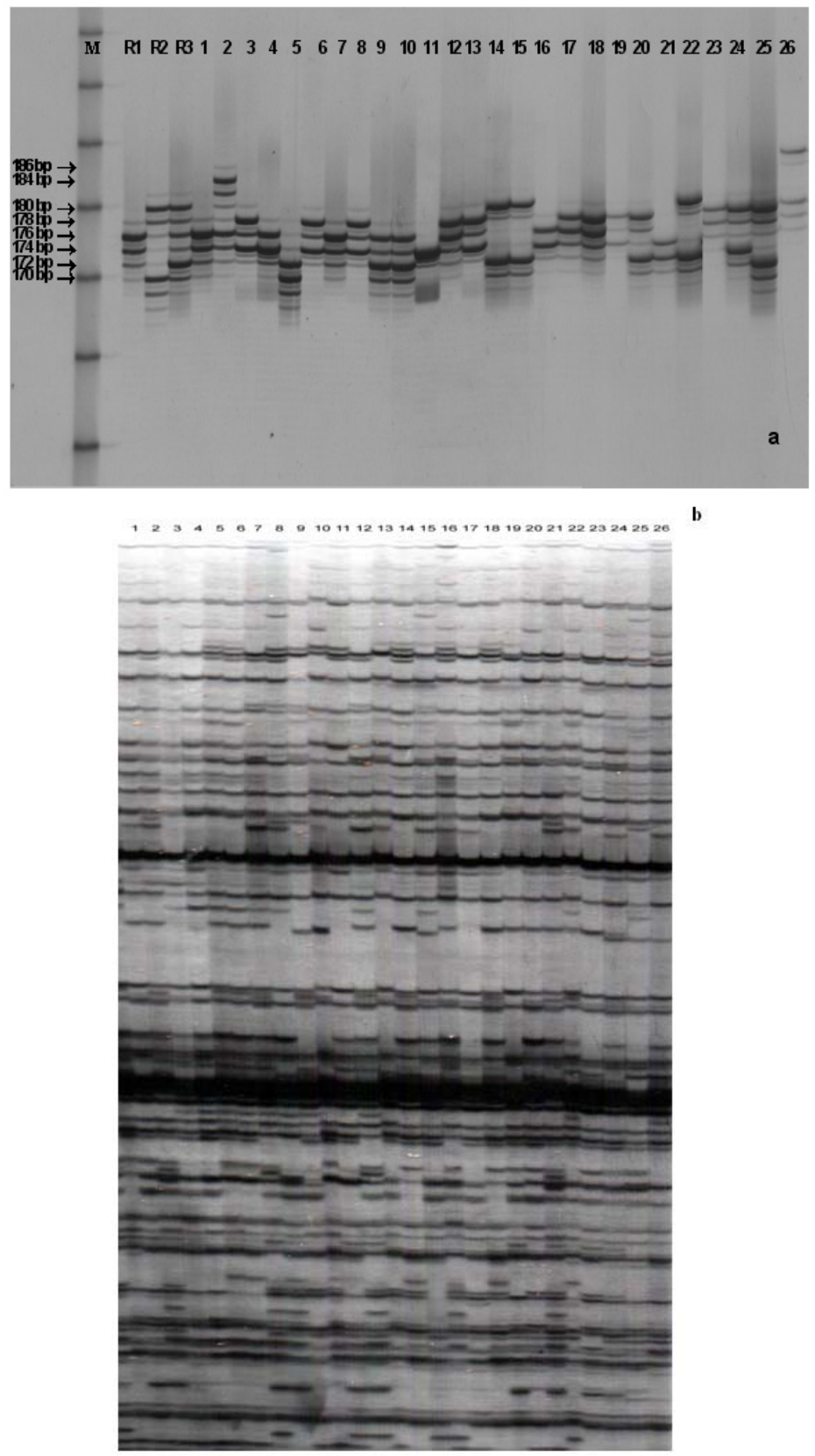

Figure 1. An example of the different information content observed with SSRs (a) and AFLPs (b). 'Meski' (1), 'Sayali' (2), 'Chemlali' (3), 'Gerboui' (4), 'Marsaline' (5), 'Chétoui' (6), 'Besbassi' (7), 'Kchinet Sig' (8), 'Neb Djemel' (9), 'Dhokkar' (10), 'Oueslati' (11), 'Mongar Ragma' (12), 'Swabaa Algia' (13), 'Semni'(14), 'Kbiret Louzir' (15), 'Jdallou' (16), 'Injassi' (17), 'Chemchali' (18), 'Rakhami' (19), 'Toffahi' (20), 'Zarrazi' (21), 'El Hor' (22), 'Ain Jarbouaa' (23), 'Jemri Dhokkar' (24), 'Unknown' (25), 'Regregui' (26). 'Coratina' (R1), 'Picholine' (R2), 'Manzanilla de Sevilla' (R3) were added for reference to allow comparison of SSR-based profiles produced by different laboratories. 


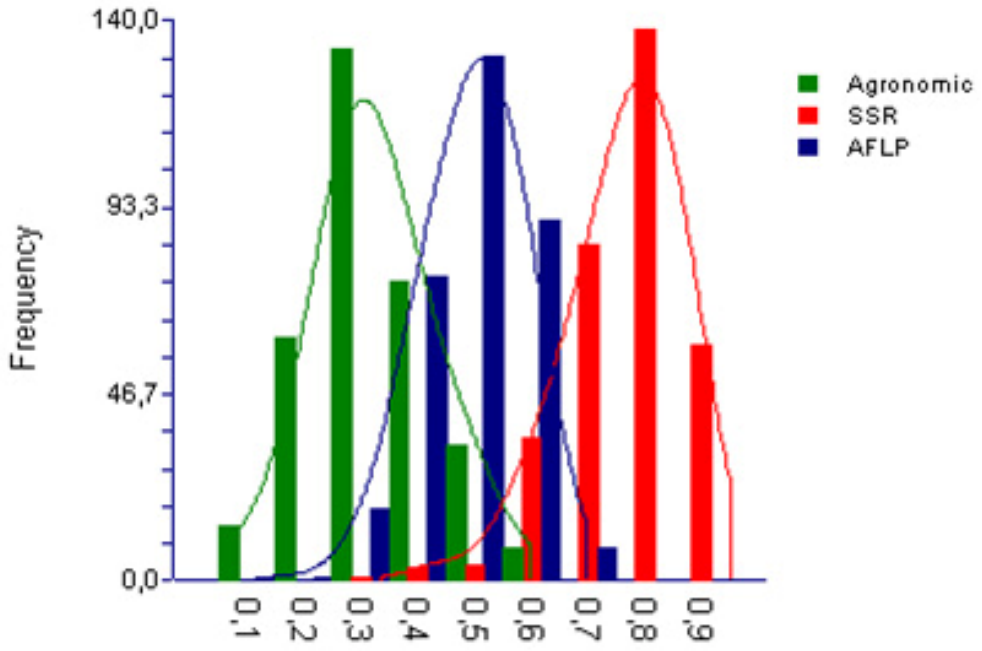

Dissimilarity

Figure 2. Frequency distribution of genetic dissimilarity among pairwise combinations of 26 Tunisian olive accessions based on agronomic, AFLP and SSR data.

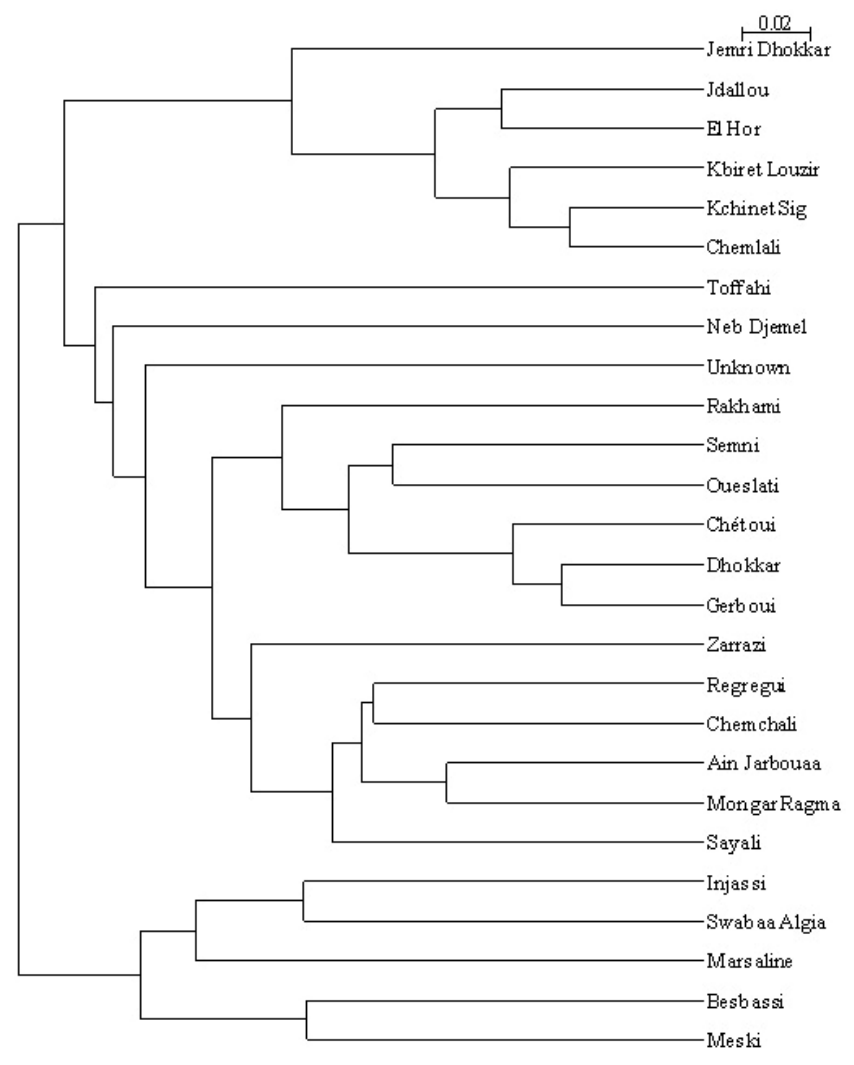

Figure 3. Dendrogram of Tunisian olive accessions derived by UPGMA from the dissimilarity matrix of the agronomical data. Distances between accessions are shown by the length of the horizontal connecting segments. A bar at the top of the figure shows a value corresponding to 0.05 units of the UPGMA parameter. 


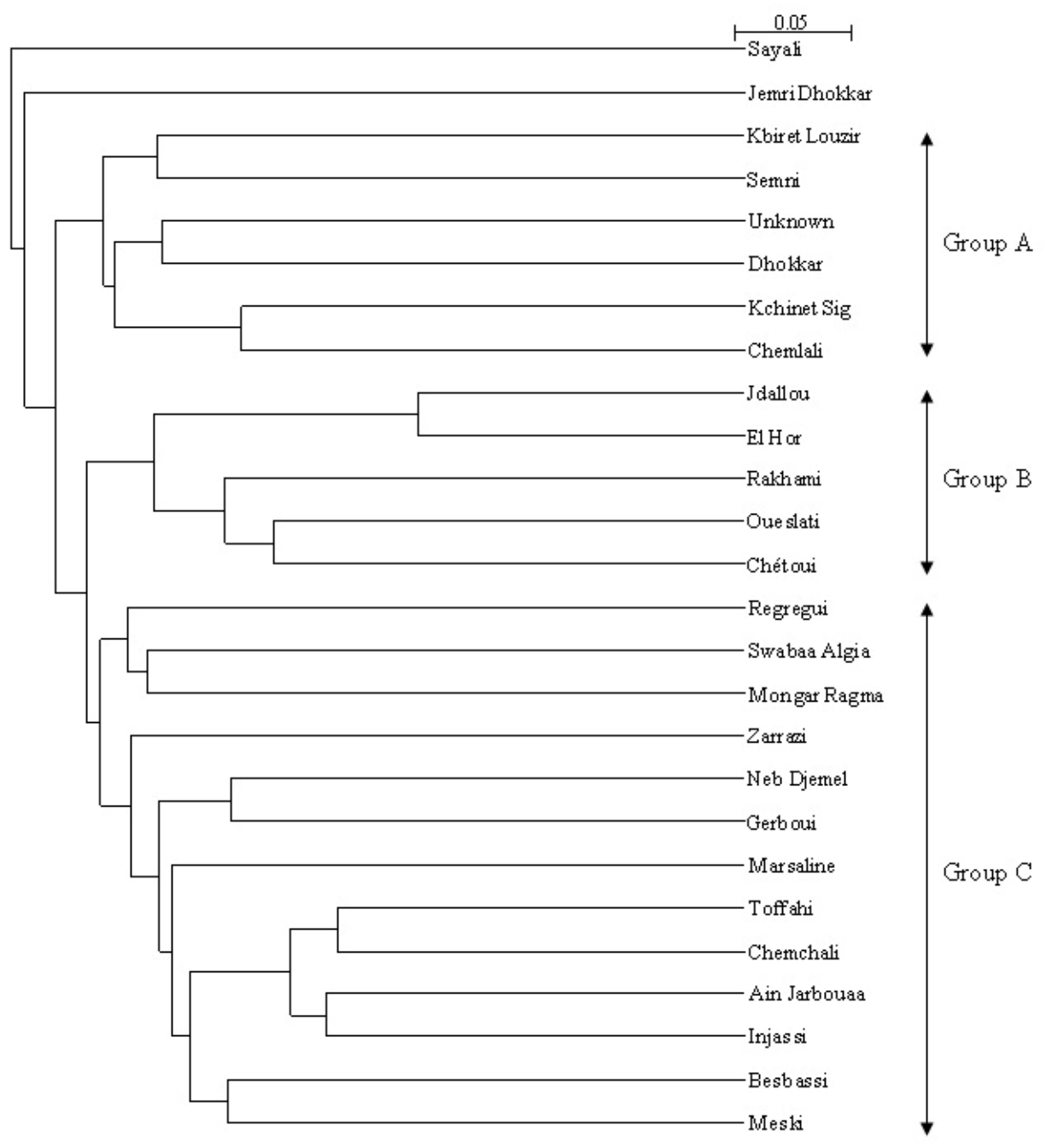

Figure 4. Dendrogram of Tunisian olive accessions derived by UPGMA from the dissimilarity matrix of the SSR-AFLP data. Distances between accessions are shown by the length of the horizontal connecting segments. A bar at the top of the figure shows a value corresponding to 0.05 units of the UPGMA parameter. 


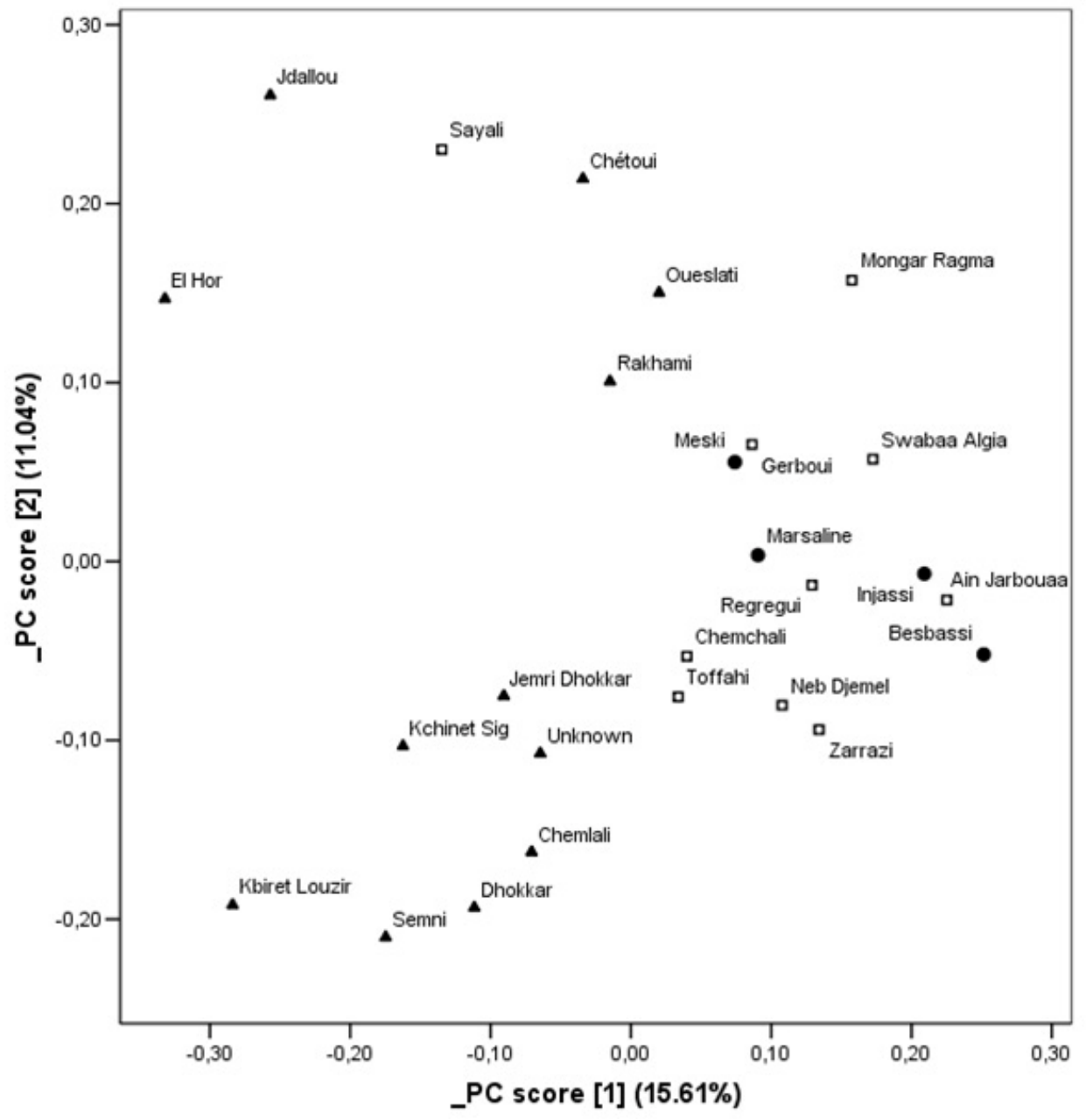

Figure 5. Principal coordinates analysis $(\mathbf{P C o A})$. Solid triangles $(\mathbf{\Delta})$ represent smallfruited cultivar accessions; squares $(\square)$ represent accessions that have medium-sized fruits.

Solid circles $(\bullet)$ represent large-fruited accessions. 


\section{TABLES}

Table 1. List of accessions studied.

\begin{tabular}{|c|c|c|c|}
\hline Accession & Use & Collection & Geographic origin \\
\hline Meski & Table & Chott Meriem & North \\
\hline Gerboui & Oil and Table & Chott Meriem & North \\
\hline Marsaline & Oil and Table & Chott Meriem & North \\
\hline Chétoui & Oil & Chott Meriem & North \\
\hline Sayali & Oil and Table & Chott Meriem & North \\
\hline Zarrazi & Oil and Table & Chott Meriem & South \\
\hline Chemlali & Oil & Chott Meriem & South \\
\hline Neb Djemel & Oil & Chott Meriem & North \\
\hline Rakhami & Oil & Chott Meriem & North \\
\hline Chemchali & Oil and Table & Chott Meriem & South \\
\hline El Hor & Oil & Sbeitla & Centre \\
\hline Oueslati & Oil & Sbeitla, & Centre \\
\hline Mongar Ragma & Oil and Table & Sbeitla & - \\
\hline Swabaa Algia & Table & Sbeitla & - \\
\hline Semni & Oil & Sbeitla & South \\
\hline Kbiret Louzir & Oil & Borj Cedria & South \\
\hline Jdallou & Oil & Borj Cedria & South \\
\hline Kchinnet Sig & Oil & Borj Cedria & South \\
\hline Injassi & Table & Borj Cedria & South \\
\hline Dhokkar & Oil & Borj Cedria & South \\
\hline Toffahi & Oil and Table & Borj Cedria & South \\
\hline Jemri Dhokkar & Oil & Borj Cedria & South \\
\hline Regregui & Oil and Table & Borj Cedria & North \\
\hline Ain Jarbouaa & Oil and Table & Borj Cedria & North \\
\hline Unknown & Oil & Borj Cedria & South \\
\hline Besbassi & Table & Borj Cedria & North \\
\hline
\end{tabular}


Table 2. Agronomic parameters used in multivariate analysis.

\begin{tabular}{|c|c|c|c|c|c|c|c|c|c|c|c|c|c|c|}
\hline & $\begin{array}{c}\text { Fruit Fresh } \\
\text { Wt (g) }\end{array}$ & $\begin{array}{c}\text { Fruit Dry } \\
\text { Wt (g) }\end{array}$ & $\begin{array}{c}\text { Stone Fresh } \\
\text { Wt }(\mathrm{g})\end{array}$ & $\begin{array}{l}\text { Flesh Fresh } \\
\text { Wt (g) }\end{array}$ & $\begin{array}{l}\text { Flesh / } \\
\text { stone }\end{array}$ & $\begin{array}{c}\text { Oil content } \\
(\%)\end{array}$ & $\begin{array}{c}\text { Oil content } \\
(\%)\end{array}$ & $\begin{array}{l}\text { Palmitic } \\
\text { acid (\%) }\end{array}$ & $\begin{array}{l}\text { Palmetoleic } \\
\text { acid (\%) }\end{array}$ & $\begin{array}{c}\text { Stearic } \\
\text { acid (\%) }\end{array}$ & $\begin{array}{c}\text { Oleic } \\
\text { acid (\%) }\end{array}$ & $\begin{array}{l}\text { Linoleic } \\
\text { acid (\%) }\end{array}$ & $\begin{array}{c}\text { Linolenic } \\
\text { acid (\%) }\end{array}$ & $\begin{array}{c}\text { Arachidic } \\
\text { acid }(\%)\end{array}$ \\
\hline Meski & 6,57 & 2,92 & 0,68 & 5,89 & 8,66 & 20,23 & 45,46 & 12,00 & 0,89 & 3,16 & 66,01 & 16,77 & 0,78 & 0,41 \\
\hline Sayali & 2,70 & 1,28 & 0,35 & 2,35 & 6,71 & 24,40 & 51,27 & 11,00 & 0,60 & 2,00 & 81,70 & 3,70 & 0,60 & 0,40 \\
\hline Chemlali & 1,05 & 0,46 & 0,17 & 0,88 & 5,18 & 18,50 & 42,00 & 17,90 & 2,30 & 2,20 & 61,30 & 15,10 & 0,70 & 0,40 \\
\hline Gerboui & 2,43 & 1,23 & 0,42 & 2,01 & 4,79 & 24,00 & 47,41 & 13,90 & 0,70 & 2,90 & 58,80 & 22,50 & 0,80 & 0,40 \\
\hline Marsaline & 4,95 & 2,11 & 0,70 & 4,25 & 6,07 & 20,00 & 46,88 & 9,35 & 0,87 & 4,91 & 76,87 & 6,90 & 0,64 & 0,45 \\
\hline Chétoui & 2,27 & 1,08 & 0,41 & 1,86 & 4,54 & 24,15 & 50,60 & 12,40 & 0,70 & 3,00 & 63,10 & 19,00 & 0,60 & 0,40 \\
\hline Besbassi & 9,22 & 3,65 & 1,06 & 8,16 & 7,70 & 18,00 & 45,43 & 14,16 & 0,83 & 2,70 & 64,60 & 16,70 & 0,59 & 0,56 \\
\hline Kchinnet Sig & 1,54 & 0,70 & 0,25 & 1,29 & 5,16 & 19,45 & 42,79 & 19,90 & 2,30 & 2,20 & 57,30 & 17,10 & 0,70 & 0,40 \\
\hline Neb Djemel & 2,88 & 1,01 & 0,53 & 2,35 & 4,43 & 17,01 & 48,45 & 13,55 & 0,94 & 2,23 & 59,78 & 21,68 & 1,32 & 0,49 \\
\hline El Hor & 1,10 & 0,58 & 0,24 & 0,86 & 3,58 & 21,40 & 40,94 & 16,10 & 2,10 & 2,13 & 68,45 & 10,11 & 0,71 & 0,40 \\
\hline Oueslati & 1,55 & 0,73 & 0,23 & 1,32 & 5,74 & 26,56 & 56,39 & 11,20 & 0,60 & 2,70 & 69,90 & 14,60 & 0,60 & 0,40 \\
\hline Mongar Ragma & 3,01 & 1,10 & 0,47 & 2,54 & 5,40 & 19,00 & 51,99 & 11,86 & 0,76 & 1,86 & 73,53 & 10,71 & 0,86 & 0,42 \\
\hline Swabaa Algia & 3,10 & 1,45 & 0,53 & 2,57 & 4,85 & 19,20 & 41,04 & 14,95 & 1,01 & 3,49 & 63,67 & 15,36 & 0,87 & 0,59 \\
\hline Semni & 1,29 & 0,53 & 0,22 & 1,08 & 5,00 & 25,34 & 61,68 & 15,45 & 1,02 & 1,81 & 62,27 & 18,45 & 0,60 & 0,39 \\
\hline Kbiret Louzir & 1,33 & 0,61 & 0,20 & 1,13 & 5,65 & 21,45 & 46,77 & 15,90 & 2,10 & 2,20 & 63,30 & 15,10 & 0,70 & 0,40 \\
\hline Jdallou & 1,39 & 0,68 & 0,34 & 1,05 & 3,09 & 20,56 & 42,03 & 16,34 & 2,23 & 2,78 & 62,68 & 14,78 & 0,70 & 0,43 \\
\hline Injassi & 5,32 & 2,21 & 0,77 & 4,55 & 5,91 & 16,50 & 39,72 & 15,00 & 0,90 & 2,70 & 69,10 & 11,30 & 0,50 & 0,50 \\
\hline Chemchali & 3,01 & 1,09 & 0,32 & 2,69 & 8,41 & 19,62 & 54,18 & 14,00 & 0,90 & 2,70 & 71,10 & 10,30 & 0,50 & 0,50 \\
\hline Toffahi & 3,12 & 1,67 & 0,44 & 2,68 & 6,09 & 33,40 & 62,40 & 12,00 & 2,00 & 2,01 & 70,20 & 12,70 & 0,55 & 0,33 \\
\hline Zarrazi & 3,65 & 1,78 & 0,47 & 3,18 & 6,77 & 29,55 & 60,48 & 8,84 & 0,47 & 3,35 & 73,75 & 12,50 & 0,60 & 0,48 \\
\hline Dhokkar & 2,01 & 1,12 & 0,30 & 1,71 & 5,70 & 27,00 & 48,46 & 12,90 & 0,70 & 2,90 & 60,80 & 21,50 & 0,80 & 0,40 \\
\hline Ain Jarbouaa & 4,02 & 1,50 & 0,51 & 3,51 & 6,88 & 20,95 & 56,15 & 11,55 & 1,13 & 2,86 & 73,37 & 10,25 & 0,83 & 0,41 \\
\hline Jemri Dhokkar & 1,30 & 0,77 & 0,27 & 1,03 & 3,81 & 23,30 & 39,27 & 20,86 & 2,19 & 3,52 & 55,28 & 16,89 & 0,67 & 0,60 \\
\hline Unknown & 0,95 & 0,41 & 0,11 & 0,84 & 7,33 & 23,95 & 55,49 & 9,60 & 0,40 & 3,79 & 68,77 & 15,15 & 0,69 & 0,69 \\
\hline Rakhami & 1,98 & 0,88 & 0,47 & 1,51 & 3,21 & 21,02 & 47,45 & 8,33 & 0,49 & 3,46 & 70,67 & 15,74 & 0,89 & 0,41 \\
\hline Regregui & 2,83 & 1,26 & 0,33 & 2,50 & 7,58 & 18,95 & 42,56 & 10,11 & 1,06 & 2,25 & 72,19 & 13,30 & 0,65 & 0,42 \\
\hline
\end{tabular}


Table 3. Descriptive statistics analysis of agronomic traits.

\begin{tabular}{|l|c|c|c|c|c|}
\hline & Minimum Maximum & Mean & $\begin{array}{c}\text { Standard } \\
\text { Deviation }\end{array}$ & $\begin{array}{c}\text { Coefficient of Variation } \\
\text { (\%) }\end{array}$ \\
\hline Fruit Fresh Wt (g) & 0.950 & 9.220 & 2.868 & 1.915 & 66.780 \\
\hline Fruit Dry Wt (g) & 0.410 & 3.650 & 1.262 & 0.772 & 61.158 \\
\hline Pit Fresh Wt (g) & 0.110 & 1.060 & 0.415 & 0.212 & 51.194 \\
\hline Flesh Fresh Wt (g) & 0.840 & 8.160 & 2.453 & 1.717 & 69.970 \\
\hline Flesh to pit ratio (Fresh Wt basis) & 3.090 & 8.660 & 5.702 & 1.509 & 26.465 \\
\hline Oil content (Fruit Fresh Wt basis) & 16.500 & 33.400 & 22.057 & 3.987 & 18.074 \\
\hline (\%) & & & & 6.896 & 14.147 \\
\hline Oil content (Fruit Dry Wt basis) (\%) & 39.270 & 62.400 & 48.742 & 6.896 & 24.034 \\
\hline Palmitic acid (\%) & 8.330 & 20.860 & 13.429 & 3.227 & 56.355 \\
\hline Palmetoleic acid (\%) & 0.400 & 2.300 & 1.161 & 0.654 & 25.750 \\
\hline Stearic acid (\%) & 1.810 & 4.910 & 2.762 & 0.711 & 9.631 \\
\hline Oleic acid (\%) & 55.280 & 81.700 & 66.865 & 6.440 & 30.405 \\
\hline Linoleic acid (\%) & 3.700 & 22.500 & 14.546 & 4.423 & 23.373 \\
\hline Linolenic acid (\%) & 0.500 & 1.320 & 0.710 & 0.166 & 18.182 \\
\hline Arachidic acid (\%) & 0.330 & 0.690 & 0.449 & 0.082 & \\
\hline
\end{tabular}

Table 4. Primer combinations and level of polymorphism obtained by AFLP.

\begin{tabular}{|l|c|c|c|c|}
\hline \multicolumn{1}{|c|}{ Primer pair combination } & $\begin{array}{c}\text { Number of } \\
\text { polymorphic } \\
\text { fragments }\end{array}$ & $\begin{array}{c}\text { Total number of } \\
\text { amplified } \\
\text { fragments }\end{array}$ & Polymorphisms (\%) & Scored bands \\
\hline EcoRI-AAC/Msel-CAA & 47 & 88 & 53.409 & 27 \\
\hline EcoRI-AAC/Msel-CAC & 54 & 85 & 63.529 & 27 \\
\hline EcoRIAAG/Msel-CAA & 46 & 77 & 59.740 & 26 \\
\hline EcoRI-ACT/Msel-CAA & 42 & 81 & 51.852 & 21 \\
\hline EcoRI-AAC/Msel-CTT & 47 & 87 & 54.023 & 28 \\
\hline Total & 236 & 418 & 56.459 & 129 \\
\hline
\end{tabular}

Table 5. List of the SSR loci analysed.

\begin{tabular}{|l|c|c|}
\hline \multicolumn{1}{|c|}{ Locus } & Range of sizes (bp) & No. of alleles \\
\hline ssrOeUA-DCA1 & $208-240$ & 9 \\
\hline ssrOeUA-DCA3 & $232-252$ & 8 \\
\hline ssrOeUA-DCA4 & $132-188$ & 14 \\
\hline ssrOeUA-DCA7 & $129-169$ & 9 \\
\hline ssrOeUA-DCA9 & $163-209$ & 11 \\
\hline ssrOeUA-DCA11 & $129-163$ & 8 \\
\hline ssrOeUA-DCA13 & $120-140$ & 5 \\
\hline ssrOeUA-DCA15 & $244-268$ & 4 \\
\hline ssrOeUA-DCA16 & $124-182$ & 10 \\
\hline ssrOeUA-DCA18 & $170-186$ & 8 \\
\hline Average & & 8.6 \\
\hline
\end{tabular}


Table 6. Comparison of the microsatellites and AFLP data in 26 olive accessions.

\begin{tabular}{|l|c|c|}
\hline & AFLP & SSR \\
\hline Number of assay units & 5 & 10 \\
\hline Number of polymorphic bands & 236 & 86 \\
\hline Average number of polymorphic bands/assay unit & 25.8 & 8.6 \\
\hline Number of loci & 418 & 10 \\
\hline Number of loci/assay unit & 83.6 & 1 \\
\hline Average number of alleles per locus & 2 & 8.6 \\
\hline
\end{tabular}

